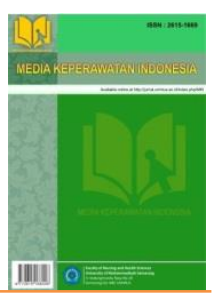

Research article

\title{
Increased Depression Affects Hyperglycemia Status in Type II Diabetes Mellitus Patients
}

\author{
Dwi Nur Aini' ${ }^{1}$, Menik Kustriyani², Arifianto $^{3}$
}

1,2,3 Program Studi S1 Keperawatan, STIKES Widya Husada Semarang

\section{Article Info}

\section{Article History:}

Accepted Oktober 3rd 2019

\section{Key words:}

Depression Level; Blood Sugar Levels of Diabetes Mellitus Type II Patients

\section{PENDAHULUAN}

Diabetes Mellitus (DM) didefinisikan sebagai penyakit kronik pada sistem endokrin yang ditandai dengan adanya peningkatan kadar gula darah akibat penurunan sekresi insulin yang progresif dilatar belakangi oleh resistensi insulin (Soewondo, 2015). Badan Kesehatan Dunia (WHO) memprediksi adanya peningkatan jumlah penyandang DM yang menjadi salah satu ancaman kesehatan global. Pada buku pedoman ini, hiperglikemia yang dibahas adalah yang terkait dengan DM tipe-2. WHO memprediksi kenaikan jumlah penyandang DM di Indonesia dari 8,4 juta pada tahun
2000 menjadi sekitar 21,3 juta pada tahun 2030. Laporan ini menunjukkan adanya peningkatan jumlah penyandang DM sebanyak 2-3 kali lipat pada tahun 2035 (PERKENI, 2015). Prediksi kenaikan jumlah penyandang DM di Indonesia dari 14,6 juta pada tahun 2017 menjadi 18,2 juta pada tahun 2045 (Cho et. al, 2017)

Indonesia menempati urutan ke 5 terbesar dari jumlah penderita diabetes melitus dengan prevalansi $6,67 \%$ dari total penduduk sebanyak 258 juta. Data penderita diabetes melitus di Jawa Tengah pada tahun 2017 dari 1.593 .931 kaus sebanyak $19,22 \%$ mengalami penyakit

Corresponding author:

Dwi Nur Aini

dwi.nuraini00@gmail.com

Media Keperawatan Indonesia, Vol 2 No 3, Oktober 2019

e-ISSN: 2615-1669

DOI:10.26714/mki.2.3.2019.121-127 
diabetes (Dinas Kesehatan Provinsi Jawa Tengah, 2018). Depresi biasanya akan terjadi pada pasiendengan diabetes dua kali lebih banyak pada umumnya, dengan 15\% sampai 30\% dari pasien diabetes yang memenuhi kriteria depresi (Piette J.D., Richardson C., Valenstein M., 2015). Hasil studi menunjukkan bahwa $43,5 \%$ pasien yang mengunjungi klinik diabetes menderita depresi (Khuwaja, A. K., et al. 2010). Studi yang lain menyebutkan bahwa dari 230 penderita diabetes melitus ditemukan sebanyak 71 orang mengalami depresi sedang dan 33 orang mengalami depresi berat dan 126 orang lainnya tidak mengalami depresi (Joseph N, et al., 2013). Penderita diabetes akan memiliki tingkat depresi lebih tinggi dibandingkan dengan yang tidak memiliki diabetes, dan berhubungan langsung dengan hiperglikemia pada penderita diabetes (Tsenkova, V., et al., 2013). Terdapat hubungan segnifikan antara depresi dan kadar gula darah dengan p value 0,0005 dan dukungan keluarga $p$ value 0,0005 . Tujuan dari penelitian ini adalah untuk mengetahui adakah hubungan tingkat depresi dengan kadar gula darah pada penderita DM tipe II.

\section{METODE}

Penelitian ini menggunakan metode kuantitatif asosiatif, dengan rancangan korelasional yang bertujuan untuk mengetahui hubungan satu variabel dengan variabel lain. Variabel independen dalam penelitian ini adalah tingkat depresi dan variabel dependen kadar gula darah pada penderita diabetes melitus tipe II. Populasi dalam penelitian ini adalah rata-rata kunjungan dalam 1 bulan terakhir di Poli Penyakit Dalam sebanyak 74 orang. Tehnik pengambilan sampel yang digunakan dalam penelitian ini adalah purposive sampling. Kriteria inklusi yang digunakan peneliti adalah pasien DM lebih dari 1 tahun, menderita DM Tipe II dan bersedia menjadi responden. Untuk memperoleh data responden peneliti menggunakan kuesioner Hamilton Rating Scale for depression (HRS - D) yang sudah baku. Analisa bivariat dalam penelitian ini menggunakan uji rank spearman untuk mengetahui adanya hubungan diantara variabel. Sampel pada penelitian ini adalah penderita diabetes melitus tipe II di RSUD H Soewondo Kendal sebanyak 62 responden. Penelitian di laksanakan pada bulan juni 2018 di RSUD H Soewondo.

Proses pengumpulan data dalam penelitian ini diawali dengan melakukan informed consent, yang sebelumnya peneliti menjelaskan tehnik penelitian yang akan dilakukan. Kemudian peneliti melakukan penelitian dengan membagikan kuesioner untuk diisi oleh responden yang sesuai dengan kriteria inklusi yang ditetapkan oleh peneliti. Proses pengolahan data dalam penelitian ini adalah, dimulai dengan melakukan editing untuk melakukan pengecekan dari jawaban responden, selanjutnya peneliti melakukan koding dan entry data dari hasil kuesioner yang telah diisi oleh responden. Proses pengolahan data yang terakhir adalah melakukan melakukan cleaning untuk melihat kemungkinan-kemungkinan adanya kesalahan-kesalahan kode, ketidaklengkapan dan kemudian melakukan pembetulan atau koreksi.

Etika penelitian yang dipakai dalam penelitian ini yaitu dengan memberikan lembar persetujuan (Informed Consent), responden diminta untuk mengisi lembar persetujuan sebelum mengisi instrumen penelitian, saat responden mengisi tidak ada unsur paksaan. Selain itu peneliti juga tidak menuliskan nama lengkap, hanya menuliskan initial nama, untuk menjaga kerahasiaan. Penelitian ini memiliki unsur manfaat (Beneficiency) saat pelaksanaan penelitian responden tidak ada responden yang mengundurkan diri dari penelitian dan responden mendapatkan kuesioner yang sama dan perlakuan yang sama dalam pelaksanan penelitian. 
HASIL

Penelitian ini dilakukan pada pasien diabetes melitus tipe 2 di di RSUD $\mathrm{H}$ Soewondo Kendal sebanyak 62 responden. Tabel 1 menunjukan bahwa rata-rata sebagian besar responden dengan umur 41 - 50 tahun (56,5\%). Karakteristik responden berdasarkan jenis kelamin terbanyak perempuan sebesar 45 responden $(72,6 \%)$. Pendidikan rata-rata sebagian besar lulusan SD sebanyak 30 responden $(48,4 \%)$, pekerjaan rata-rata sebagian besar ibu rumah tangga sebanyak 29 responden (46,8\%). Sebagian besar pasien mengalami depresi sedang yaitu sebanyak 27 responden $(43,5 \%)$ ditunjukkan dalam tabel 1. Sedangkan kadar gula darah pasien menunjukkan bahwa responden rata-rata sebagian besar memiliki kadar gula darah Buruk yaitu sebanyak 42 responden $(67,7 \%)$.

Tabel 1

Karakteristik Responden pasien diabetes melitus tipe II

\begin{tabular}{lcc}
\hline \multicolumn{1}{c}{ Indikator } & $\mathrm{f}$ & $\%$ \\
\hline Umur & & \\
1. $30-40$ tahun & 2 & 3,2 \\
2. $41-60$ tahun & 35 & 56,5 \\
3. >60 tahun & 25 & 40,3 \\
\hline Jenis Kelamin & & \\
1. Laki-laki & 17 & 31,8 \\
2. Perempuan & 45 & 68,2 \\
\hline Pendidikan & & \\
1. Lulusan SD & 30 & 48,4 \\
2. Lulusan SMP & 16 & 25,8 \\
3. LulusanSMA & 9 & 14,5 \\
4. Perguruan Tinggi & 7 & 11,3 \\
\hline Pekerjaan & & \\
1. IRT & 29 & 46,8 \\
2. Pegawai Negeri & 7 & 11,3 \\
3. Karyawan Swasta & 11 & 17,7 \\
4. Wiraswasta & 9 & 14,5 \\
5. Buruh & 6 & 9,7 \\
\hline Tingkat Depresi & & \\
1. Ringan & 15 & 24,2 \\
2. Sedang & 27 & 43,5 \\
3. Berat & 20 & 32,3 \\
\hline GDS & 9 & 14,5 \\
1. Baik & 11 & 17,7 \\
2. Sedang & 42 & 67,7 \\
3. Buruk & & \\
\hline
\end{tabular}

Responden dengan tingkat depresi ringan dengan kadar gula darah baik sebanyak 6 responden $(9,7 \%)$. Tingkat depresi ringan dengan kadar gula darah sedang sebanyak 6 responden $(9,7 \%)$. Tingkat depresi ringan dengan kadar gula darah buruk sebanyak 3 responden $(4,8 \%)$. Tingkat depresi sedang dengan kadar gula darah baik sebanyak 2 responden $(3,2 \%)$. Tingkat depresi sedang dengan kadar gula darah sedang sebanyak 4 responden (6,5\%). Tingkat depresi sedang dengan kadar gula darah buruk sebanyak 21 responden $(33,9 \%)$. Tingkat depresi berat dengan kadar gula darah baik sebanyak 1 responden (1,6\%). Tingkat depresi berat dengan kadar gula darah sedang sebanyak 1 responden $(1,6 \%)$. Tingkat depresi berat dengan kadar gula darah buruk sebanyak sebanyak 18 responden $(29,0 \%)$

Analisa data dengan menggunakan uji rank spearman di dapatkan $p$ value $=0,000$ maka dapat disimpulkan bahwa ada hubungan tingkat depresi dengan kadar gula darah pada penderita diabetes melitus tipe II di puskesmas mijen kota semarang. Dari hasil analisis diperoleh pula nilai $r=0,524$ hal ini menunjukkan bahwa terdapat hubungan positif sebesar 0,524 yaitu berada dalam kekuatan korelasi sedang dengan arah korelasi searah. Nilai positif pada koefisien korelasi $r$ menunjukkan bahwa semakin tinggi tingkat nilai depresi maka nilai kadar gula darah semakin tinggi.

Tabel 2

Hubungan Tingkat Depresi dengan gula darah pasien Diabetes melitus tipe II

\begin{tabular}{ccc}
\hline Indikator & $\begin{array}{c}\text { Koefisien } \\
\text { korelasi }\end{array}$ & $\begin{array}{c}\mathbf{P} \\
\text { Value }\end{array}$ \\
\hline $\begin{array}{c}\text { Hubungan tingkat depresi } \\
\text { dengan gula darah pasien }\end{array}$ & 0,524 & $0,000^{*}$ \\
\hline Spearman rank test* & &
\end{tabular}

\section{PEMBAHASAN}

Hasil penelitian ini menunjukkan bahwa usia rata-rata terdapat pada responden berumur 41 - 60 tahun sejumlah 35 orang dari total responden. Hasil penelitian ini 
sama dengan penelitian Masriadi (2012), bahwa umur merupakan faktor resiko karena dari semua penyandang diabetes melitus tipe II dialami oleh individu yang berusia diatas 40 tahun dan menurut teori dari Juddin, (2017) bahwa pertumbuhan usia memengaruhi kadar gula darah seseorang, seseorang yang mengalami hiperglikemia cenderung lebih banyak berada di umur 41 - 60 tahun dibandingkan dengan responden yang berumur dibawah 40 tahun. Sebuah studi) mengatakan bahwa terdapat perbedaan yang signifikan dan hubungan yang positif antara usia dan ratarata kadar glukosa darah (Veghari et. al., 2010). Data menunjukkan bahwa orang dengan usia 55-65 tahun, lima kali lebih banyak menderita penyakit diabetes mellitus dibandingkan orang dengan rentang usia antara 25-35 tahun. Penderita Diabetes Melitus tipe II di RSUD H Soewondo Kendal lebih banyak berjenis kelamin perempuan yaitu 45 respoden $(72 \%, 6)$ dari pada laki - laki. perempuan mempunyai peluang lebih besar diakibatkan Sindroma siklus bulanan (premenstrual syndrome), pascamenopause yang membuat distribusi lemak tubuh menjadi mudah terakumulasi akibat proses hormonal tersebut sehingga wanita berisiko menderita diabetes melitus (Irawan, 2010).

Hasil penelitian menunjukan bahwa sebagian responden penderita diabetes melitus tipe II memiliki tingkat depresi sedang sebanyak 27 responden $(43,5 \%)$. Hal ini sejalan dengan penelitian yang dilakukan Mujabi, (2017) menunjukan bahwa sebagian besar responden memiliki depresi dalam katagori sedang yaitu 29 responden (53\%) dan sisanya depresi ringan sebanyak 26 responden (47\%). Studi menunjukkan bahwa 43,5\% pasien yang mengunjungi klinik diabetes menderita depresi (Khuwaja, A. K., et al., 2010). Pada penderita penyakit kronis, seperti diabetes melitus, prevalensi depresi dapat meningkat sampai dua kali lipat dibandingkan populasi normal. Pasien diabetes melitus dengan depresi memiliki tingkat kesehatan yang jauh lebih buruk daripada pasien yang hanya mengidap diabetes melitus saja ataupun depresi saja. Hal ini tampak pada pasien yang hidup dengan penyakit kronis seperti penyakit diabetes melitus tipe II dapat mempengaruhi kondisi psikologis bagi penderita (Kurniati, 2017).

Hasil penelitian di RSUD $\mathrm{H}$ Soewondo Kendal didapatkan pada responden penderita diabetes melitus tipe II dengan tingkat depresi ringan tidak didapatkan tanda gejala pada mood depresi, namun terdapat gejala pada insomnia inisial. Hal ini diungkapkan responden kadang - kadang sukar tidur. Selain itu responden juga mengalami agitasi yaitu kadang - kadang responden mengalami gelisah dan anxiety psikologis berupa responden merasa cemas terhadap permasalahan kecil. sedangkan pada responden dengan tingkat depresi sedang terdapat gejala mood depresi seperti merasa kesedihan dan perasaan bersalah seperti menyalahkan diri sendiri.

Selain itu juga responden mengalami tanda gejala anxiety psikologis ditandai dengan perasaan takut karena tidak ada penurunan kadar gula darah, selain itu responden juga mengalami insomnia tertunda seperti kadang - kadang terbangun malam hari namun dapat dapat tidur lagi. Pada respoden dengan tingkat depresi berat didapatkan tanda gejala pada insomnia tertunda, hal ini diungkapkan responden sering bangun pada malam hari dan kadang - kadang tidak dapat tidur lagi karena adanya suatu penyakit atau akibat adanya permasalahan psikologi yang dialami responden. Selain itu responden juga mengalami penurunan produktifitas dan gejala somatis umum seperti mengalami gejala fisik yaitu rasa sakit serta hilang tenaga dan kelelahan. Responden juga mengalami kehilangan berat badan yang terlihat jelas.

Upaya yang dilakukan untuk mengurangi tingkat depresi pada penderita diabetes melitus tipe II menurut Hasanat, (2010) 
yaitu dengan melakukan aktifitas fisik untuk meningkatkan energy serta stamina, meningkatkan pemantauan kadar gula darah serta dukungan social, dukungan sosial merupakan tindakan yang sifatnya membantu dengan melibatkan emosi, pemberian informasi, bantuan materi dan penilaian yang positif pada individu dalam menghadapi permasalahannya. Dukungan tersebut berkaitan dengan pembentukan keseimbangan mental dan kepuasan psikologi. Dukungan social pada penderita diabetes melitus tipe II dapat diperoleh dari anggota keluarga, teman, kerabat maupun paramedik yang merupakan sumber eksternal yang dapat memberikan bantuan bagi penderita diabetes dalam mengatasi dan menghadapi suatu permasalahan terutama yang menyangkut penyakit yang diderita (Sari, 2016). dukungan keluarga merupakan faktor yang penting yang mempengaruhi terjadinya depresi. Dengan adanya dukungan social yang diperoleh dari orang terdekat yaitu keluarga dapat menurunkan kecenderungan munculnya kejadian yang mengakibatkan stress, adanya interaksi dengan kelurga dapat memodifikasi atau mengubah persepsi individu pada kejadian stress, sehingga akan mengurangi potensi munculnya depresi.

Hasil penelitian di RSUD $\mathrm{H}$ Soewondo Kendal menunjukan bahwa sebagian besar responden memiliki kadar gula darah buruk 41 responden Hal ini sejalan dengan penelitian yang dilakukan oleh Derek, (2017) di Rumah Sakit Pancaran Kasih Gmim Manado diperoleh bahwa kadar gula darah diabetes melitus tipe II yaitu responden kadar gula darah buruk sebanyak 39 responden (52,0\%) dan kadar gula darah sedang sebanyak 36 responden (48,0\%). Hal tersebut sebagaimana dikemukakan oleh Mujabi, (2017) bahwa diabetes melitus adalah suatu sindroma yang ditandai dengan peningkatan kadar glukosa darah disebabkan oleh karena adanya kelainan sel beta pulau Langerhans kelenjar pankreas, pada diabetes melitus tipe II kadar glukosa darah meningkat karena adanya resistensi insulin akibat gaya hidup yang salah. Diabetes mellitus merupakan merupakan suatu kelompok penyakit metabolik dengan karakteristik hiperglikemia yang terjadi karena kelainan sekresi insulin, kerja insulin atau keduanya. Hasil penelitian yang dilakukan didapatkan pada responden penderita diabetes melitus tipe II dengan kadar gula darah baik didapatkan responden yang rutin minum obat, menjalankan diet yang dianjurkan oleh dokter dan mengecek kadar gula darah secara rutin, pada responden dengan kadar gula darah sedang didapatkan pasien memang rutin minum obat namun pasien belum menjalankan diet dengan baik seperti responden masih sering minum dan makan makanan yang terlalu manis dan pada responden dengan kadar gula darah buruk dari informasi yang didapatkan responden hanya periksa dan meminum obat ketika sudah terjadi keluhan

Hasil penelitian menunjukkan adanya hubungan tingkat depresi dengan kadar gula darah pada penderita diabetes melitus tipe II di RSUD H Soewondo Kendal. Hasil penelitian ini sesuai dengan penelitian yang dilakukan oleh Mujabi, (2017) dengan judul hubungan kadar gula darah dengan tingkat depresi dan aktivitas fisik pada penderita diabetes melitus di Puskesmas Gatak Sukoharjo dengan sampel 55 responden didapatkan hasil analisis diperoleh nilai signifikan 0,000. dengan kekuatan hubungan nilai $r$ sebesar 0,460. menunjukkan adanya korelasi positif yang signifikan antara depresi dengan kadar gula darah pada penderita diabetes melitus tipe II dengan kekuatan korelasi sedang, artinya semakin tinggi tingkat depresi maka semakin tinggi pula kadar gula darahnya

Penderita diabetes akan memiliki tingkat depresi lebih tinggi dibandingkan dengan yang tidak memiliki diabetes, dan berhubungan langsung dengan hiperglikemia pada penderita diabetes (Tsenkova et. Al., 2013). Kondisi hiperglikemia pada waktu yang panjang akan mengalami kerusakan di berbagai 
organ (Nindyasari, 2010). Depresi dapat mempengaruhi kadar gula dalam darah. Dampak yang ditimbulkan dari depresi yaitu naiknya gula darah disebabkan meningkatnya glikogenolisis dihati dan peningkatan glucagon terhambat pengambilan glukosa oleh otot dan berkurangnya pembentukan insulin pada pankreas (Sari, 2016). Depresi pada pasien diabetes menyebabkan pesimisme dan menurunkan self-efficacy, dan dapat mengakibatkan kepatuhan serta perawatan diri yang kurang, selain itu menunjukan bahwa depresi pada pasien diabetes melitus tipe II lebih parah dengan beban gejala yang lebih tinggi, peningkatan penurunan fungsional, control glikemik yang kurang dan komplikasi diabetes yang tinggi (Zuberi et. Al., 2015). penelitian ini sesuai dengan penelitian yang dilakukan oleh Mujabi, (2017) dengan judul hubungan kadar gula darah dengan tingkat depresi dan aktivitas fisik pada penderita diabetes melitus di Puskesmas Gatak Sukoharjo dengan sampel 55 responden didapatkan hasil analisis diperoleh nilai signifikan 0,000. dengan kekuatan hubungan nilai $r$ sebesar 0,460. menunjukkan adanya korelasi positif yang signifikan antara depresi dengan kadar gula darah pada penderita diabetes melitus tipe II dengan kekuatan korelasi sedang, artinya semakin tinggi tingkat depresi maka semakin tinggi pula kadar gula darahnya

\section{SIMPULAN}

Peningkatan depresi berhubungan dengan peningkatan gula darah pasien diabetes melitus tipe II.

\section{UCAPAN TERIMAKASIH}

Ucapan terimakasih kami berikan kepada seluruh responden yang terlibat dalam penelitian ini, Direktur RSUD H Soewondo Kendal, Ketua STIKES Widya Husada Semarang, Ketua Program Studi Ners STIKES Widya Husada Semarang dan Ketua Pusat Penelitian dan Pengabdian Masyarakat STIKES Widya Husada Semarang.

\section{REFERENSI}

Cho, N. H. (2017). IDF Diabetes Atlas Eighth edition 2017. International Diabetes Federation.

Derek, M. I. (2017). Hubungan Tingkat Stres Dengan Kadar Gula Darah Pada Pasien Diabetes Melitus Tipe Ii Di Rumah Sakit Pancaran Kasih Gmim. Manado: FKU Sam Ratulangi.

Dinas Kesehatan Provinsi Jawa Tengah. (2018). Profil Kesehatan Provinsi Jawa Tengah Tahun 2017. Semarang: Dinas Kesehatan Provinsi Jawa Tengah.

Hasanat, N. U. (2010). Program Psikoedukasi Bagi Pasien Diabetes Untuk Meningkatkan Kualitas Hidup. Yogyakarta: Universitas Gajah Mada.

Irawan, D. (2010). Prevalensi dan Faktor Risiko Kejadian Diabetes Melitus Tipe 2 di Daerah Urban Indonesia (Analisa Data Skunder Riskesdas 2007). Jakarta: Universitas Indonesia.

Juddin, D. R. (2017). Hubungan tingkat pengetahuan faktor resiko DM dengan status DM pada pegawai negeri sipil alauddin makasar. http://www.jurnal.ummu.ac.id/index.php/BI OSAINSTEK/article/download/211/131/. Makasar: FKK Uin Alauddin Makasar.

Kurniati, E. (2017). HUBUNGAN TINGKAT DEPRESI DENGAN KUALITAS TIDUR PASIEN DIABETES MELLITUS TIPE 2 DI POLI PENYAKIT DALAM RSUD PANEMBAHAN SENOPATI BANTUL. Yogyakarta: STIKES Jenderal Achmad Yani Yogyakarta.

Masriadi. (2012). Epidemiologi Diabetes Melitus. Yogyakarta: Penerbit Ombak.

Mujabi, M. F. (2017). Hubungan Kadar Gula Darah Dengan Tingkat Depresi Dan Keaktifan Fisik Pada Penderita Diabetes Melitus Di Puskesmas Gatak Sukoharjo. Surakarta: FKU Muhamadiyah Surakarta.

Nindyasari, N. (2010). Perbedaan Tingkat Kecemasan Pada Penderita Diabetes Melitus (DM) Tipe I Dengan Diabetes Melitus (DM) Tipe I. Surakarta: Universitas Sebelas Surakarta.

PERKENI. (2015). Konsensus Pengelolaan dan Pencegahan Diabetes Melitus Tipe 2 di Indonesia 2015. Jakarta: PB. PERKENI. 
Tsenkova, V. A. (2013). Trait Anxiety and glucose Metabolism in People Without Diabetes : Vulnerabilities Among Black Women. Diabet Med , 24(6); $803-806$.

Tsenkova, V., Albert, M., Georgiades, A., Ryff, C. (2013). Trait Anxiety and glucose Metabolism in People Without Diabetes : Vulnerabilities Among Black Women. Diabet Med , 24 (6). 803-806.

Veghari, G. S. (2010). Association between sociodemographic factors and diabetes mellitus in the north of Iran: A population-based study. International Journal of Diabetes Mellitus , Volume 2, Issue 3, December 2010, Pages 154-157.

Zuberi, S. S. (2015). Association of adaepression aawith atareatment Outcomes in type 2 Diabetes Melitus : a cross- sectional study from Karachi, Pakistan. Pakistan: BMC Pschiatry. 